\title{
Educational interventions on breast cancer in men and women: a necessity in primary healthcare
}

\author{
Ortega Jiménez Mayra del Carmen ${ }^{1,2}$, García Rodríguez Deysi Emilia ${ }^{3}$, Brenda Hidalgo Mares ${ }^{4}$ and Ortega Jiménez Marcela ${ }^{4}$ \\ ${ }^{1}$ Department of Nursing and Obstetrics, University of Guanajuato, Celaya, CP38110, Mexico \\ ${ }^{2}$ Doctoral Studies, Universidad Internacional Iberoamericana (UNINI-Mexico), Campeche, CP 24560 Mexico \\ ${ }^{3}$ Universidad Internacional Iberoamericana (UNINI-Mexico), Campeche, CP 24560, Mexico \\ ${ }^{4}$ Department of Nursing and Obstetrics, University of Guanajuato, Celaya CP38110, Mexico
}

\section{Abstract}

Breast cancer $(\mathrm{BC})$ is one of the most common diseases in the global population. It most commonly presents in women; however, there has been an increase in the number of men diagnosed with the disease, although at a lower rate. Its specific characteristics and associated risk factors mean that preventative measures are considered to be one of the most important methods of avoiding BC. Therefore, education is a fundamental part of this process. The objective of this study is to report on the educational interventions on BC carried out in healthcare between 2016 and 2021. To this end, an integrative review was carried out using the following databases: PubMed (NCBI), Science Direct, Scopus, SciELO and Google Scholar, using the keywords 'breast cancer', 'intervention education', 'prevention' and the Boolean operator 'AND'. Quantitative, full-text articles in English, Spanish or Portuguese were included. Finally, 19 articles were selected for analysis and it was found that, with regard to educational interventions on BC carried out in healthcare, one article included men and women and the remaining 18 included only women, with interventions carried out in sessions, workshops, in stages and using dynamic techniques. Therefore, there is a pressing need for educational interventions on BC for men and women at all stages of life; however, priority should be given to the young population in order to allow for early prevention. These interventions do not generate costs for the health sector, but they have a positive effect by increasing knowledge and promoting self-care.

Keywords: breast cancer, intervention education, prevention, primary

\section{Introduction}

Breast cancer $(\mathrm{BC})$ is a malignant disease where the rapid, abnormal and uncontrolled spread of cells in the different tissue types found in the mammary gland, such as epithelial cells of the mammary ducts or lobules, form a tumour that invades neighbouring tissues and metastasises to other organs in the body [1].

\author{
Correspondence to: Ortega Jiménez Mayra del \\ Carmen \\ Email: mdc.ortega@ugto.mx \\ ecancer 2021, 15:1255 \\ https://doi.org/10.3332/ecancer.2021.1255
}

Published: 22/06/2021

Received: 23/03/2021

Publication costs for this article were supported by ecancer (UK Charity number 1176307).

Copyright: (c) the authors; licensee ecancermedicalscience. This is an Open Access article distributed under the terms of the Creative Commons Attribution License (http:// creativecommons.org/licenses/by/3.0), which permits unrestricted use, distribution, and reproduction in any medium, provided the original work is properly cited. 
A global study found that these diseases cause a series of economic, social and family-related issues for those suffering from chronic degenerative diseases such as BC. It has one of the highest mortality rates for those suffering from this particular disease, and it is the second most commonly diagnosed cancer globally and the most common cancer among women [2].

During a comprehensive global study, a prediction of the incidence of $\mathrm{BC}$ was made and it was determined that there will be approximately 3.2 million new cases by 2050 [3]. This will mainly affect the least developed regions of the world where $56 \%$ of new cases and $63 \%$ of deaths are reported [4]. It is estimated that women who reach 85 years of age or older will have a 1 in 9 chance of developing BC [5].

In Mexico, BC is among the three most prevalent types of cancer. It mainly affects women, and men suffer to a lesser extent. Men are at a disadvantage due to the methods used to disseminate information on the topic which tends to focus on the results of BC in women as they are more likely to develop the disease. This can lead to men believing that they cannot suffer from this type of cancer [6].

Every day, women are affected more and more by BC due to an apparent lack of preventative preparation and a lack of urgency to perform breast self-examinations at an early age. This is due to insufficient guidance that is offered to both genders on this issue. Breast carcinoma is rare before the age of 20 , but from this age the incidence rises steadily [7].

In addition, males with $\mathrm{BC}$ represents between $0.5 \%$ and $1 \%$ of all $\mathrm{BC}$ cases diagnosed worldwide, with a male to female ratio of 1:100. Even though rates have increased over the last 25 years, it generally has a poor prognosis with a poor survival rate due to the fact that most cases are diagnosed in very late stages [8]. Miao et al [9] estimated the incidence in men to be 0.40 in 100,000 people/year.

There has been a greater emphasis placed on the importance of early $B C$ detection through health promotion, with the aim of reducing morbidity and mortality rates at both international and national levels. However, this has not had a strong enough impact on the population, so more effective guidance on prevention is required. One of the main problems is the lack of knowledge as well as sociocultural factors, applicable to both men and women.

Mexico's short- and medium-term outlook regarding BC is not encouraging because the programmes that were created and implemented for prevention and early detection have not adequately curbed the number of cases and deaths from these diseases [10].

Therefore, there is a clear need for effective prevention work to be developed in the population, targeting both genders and incorporating young people, with the overarching aim of raising awareness of the importance of breast care.

$\mathrm{BC}$ diagnoses are rare among women over the age of 30, however, the development of cancer even where rates are very low can hold great significance because when it does develop, both diagnosis and treatment significantly affect quality of life [11]. This can result in premature menopause; infertility; osteoporosis; weight gain; common psychological effects such as changes to body image, cognitive function and the constant threat of recurrence and early death; as well as social effects relating to work, relationships with partners, caring for loved ones and dealing with stigma [12]. That is why interventions should be aimed at those in all stages of life.

Furthermore, it has been determined that women who live in countries with a high socioeconomic level have a higher risk of developing BC, but there is a higher risk of death among women who live in poor countries, due to the fact that they have less access to healthcare services for early detection, treatment and control of the disease [13].

Although people claim to be knowledgeable about $\mathrm{BC}$, it has been reported that people find it difficult to identify risk factors and prevention strategies, as well as specific information regarding treatment. Thus, it is necessary to improve education on preventing this type of cancer in study programmes and to encourage health promotion [14].

Understandably, the healthcare system plays a key role and it must guarantee access to services without discriminating on the basis of socioeconomic conditions, thus ensuring equal access to opportunities and quality provision of preventative, diagnostic and therapeutic services, to decrease the mortality of preventable cancers in women attributed to diagnosis and timely treatment. This can facilitate early detection and timely treatment [15].

Early detection of $\mathrm{BC}$ has been shown to reduce mortality and is an important step in reducing the burden of this disease on the public healthcare system. However, despite the infrastructure and availability of organised screening programmes, participation in screenings for many types of cancer remains below established targets [16]. 
In this regard, achieving a reduction in modifiable risk factors related to the development of BC is highly significant, and this involves promoting healthy lifestyles (HL). The fundamental aspects of this are adopting a healthy diet, controlling body weight, engaging in physical activity, limiting alcohol consumption and not smoking. Adopting a healthier lifestyle results in a $17 \%-58 \%$ decrease in BC risk factors and significantly reduces the risk of cancer morbidity and mortality, and should therefore be prioritised in the prevention of BC [17].

Poor nutrition and insufficient exercise are significant factors in the development of BC, and are related to lifestyle (diets high in carbohydrates and both animal and trans fats but low in fibre, as well as obesity and sedentary behaviour) [18]. In Latin America, there exists a common risk and epidemiological profile due to the high frequency of some risk factors, such as excess weight, obesity, low breastfeeding rates, little physical activity and hormone use. It also refers to the lack of health information, which is reflected in limited access to primary and secondary prevention services [19].

Another modifiable risk factor is associated with tobacco use. Four thousand chemicals have been found in oral tobacco products, 60 of which are considered carcinogens [20].

Additionally, alcohol consumption is also considered to be a modifiable risk factor and is associated with an increased risk of BC, because there is a linear dose-response relationship between alcohol consumption, risk and this type of cancer [21].

Another modifiable risk factor is the tendency not to undertake self-examination, as indicated in a study conducted in Lima, Peru, which reports that $62.5 \%$ of women do not know the frequency with which self-examination should be undertaken and $78.8 \%$ is not aware of its usefulness for early detection of cancer [22].

Breast self-examination should be performed by all women from the age of 20 , between the 5 th and 7 th day, after the menstrual cycle, since this is when the breasts are softer. Women who no longer have their period will have to do it on a specific day of each month, this is to create a habit and try to improve the detection technique [23].

The risk factors found suggest that it would be beneficial to develop actions that promote HL [24]. Thus, it should be oriented at all stages of a person's life, and in particular it should be started in early childhood to encourage them to take responsibility for self-care of health, to reduce risk factors where possible and promote $\mathrm{HL}$. In addition, promoting health in order to detect BC should include self-examination, clinical examination and mammography.

It is based on the assumption that the main ways to foster understanding about the prevention and characteristics of BC are through educational measures, through teaching in a friendly way to this community and at a low cost; which can have a positive impact on the early identification of cancer.

Studies associated with the effectiveness of measures carried out in this area show that educational interventions for the prevention and early detection of $\mathrm{BC}$ in women of childbearing age are effective, and that more than $60 \%$ of women gained sufficient knowledge about the prevention and early detection of BC [25].

On the other hand, in a study carried out in Mexico City that had the objective of assessing the impact of the syllabus on modifying behaviour and attitudes related to $\mathrm{BC}$ in teenagers, the results showed that the programme was successful, since the sessions included in the programme were adequate for improving the adolescents' level of knowledge about BC [26].

Educational interventions have been recommended as an effective public health approach in the comprehensive control of BC, especially among young people.

At the same time, the importance of preventive BC health education interventions, in all stages of life, is reiterated, in order to develop health-promoting behaviours that allow the detection and timely control of risks in the development of BC. Its effectiveness has been demonstrated, but the need to have the knowledge, skills and competencies necessary to be able to transmit relevant and updated education on the subject is highlighted [27].

That is why a review of the bibliography referring to health interventions in $\mathrm{BC}$ in men and women at any stage of their lives has been undertaken, in order to show the work done in this regard, highlighting its need and importance for society as a whole. This enhances the 
possibility of adopting, adapting and improving it, in order to develop a primary prevention programme in effective health associated with this pathology.

\section{Approach}

For the development of the study, a search of scientific documents was carried out in databases PubMed (NCBI), SciELO, Scopus and the Google Scholar search engine, using the descriptors 'breast cancer', 'intervention education', 'prevention', 'primary' and the Boolean operators 'AND'.

The articles included quantitative and qualitative studies, full texts, written in English, Spanish or Portuguese, published from 2016 to 2021.

For the inclusion criteria, to be considered articles needed to be full-text, published in the aforementioned databases and in the search engine, products of primary research carried out in English, Spanish or Portuguese where the concept of educational interventions in BC is addressed, focused in primary prevention applied to men, women or both in all stages of life, with the publication date 2016-2021 and based on quantitative, qualitative or mixed-focus studies.

During the period from 2019 to 2020, an exhaustive search was made in the scientific literature for articles describing educational interventions in BC, through which 137 articles were found; with 19 articles remaining to be analysed (Figure 1).

\section{Results}

In the present literature review, predominantly articles in English and Spanish were used, finding the following; eleven in PubMed, five in SciELO, zero in Scopus and three in the Google Scholar search engine, obtaining a total of 19 selected for the development of this bibliographic review.

Of the 19 articles, all of them on educational interventions of BC, one included men and women and the remaining 18 included women only.

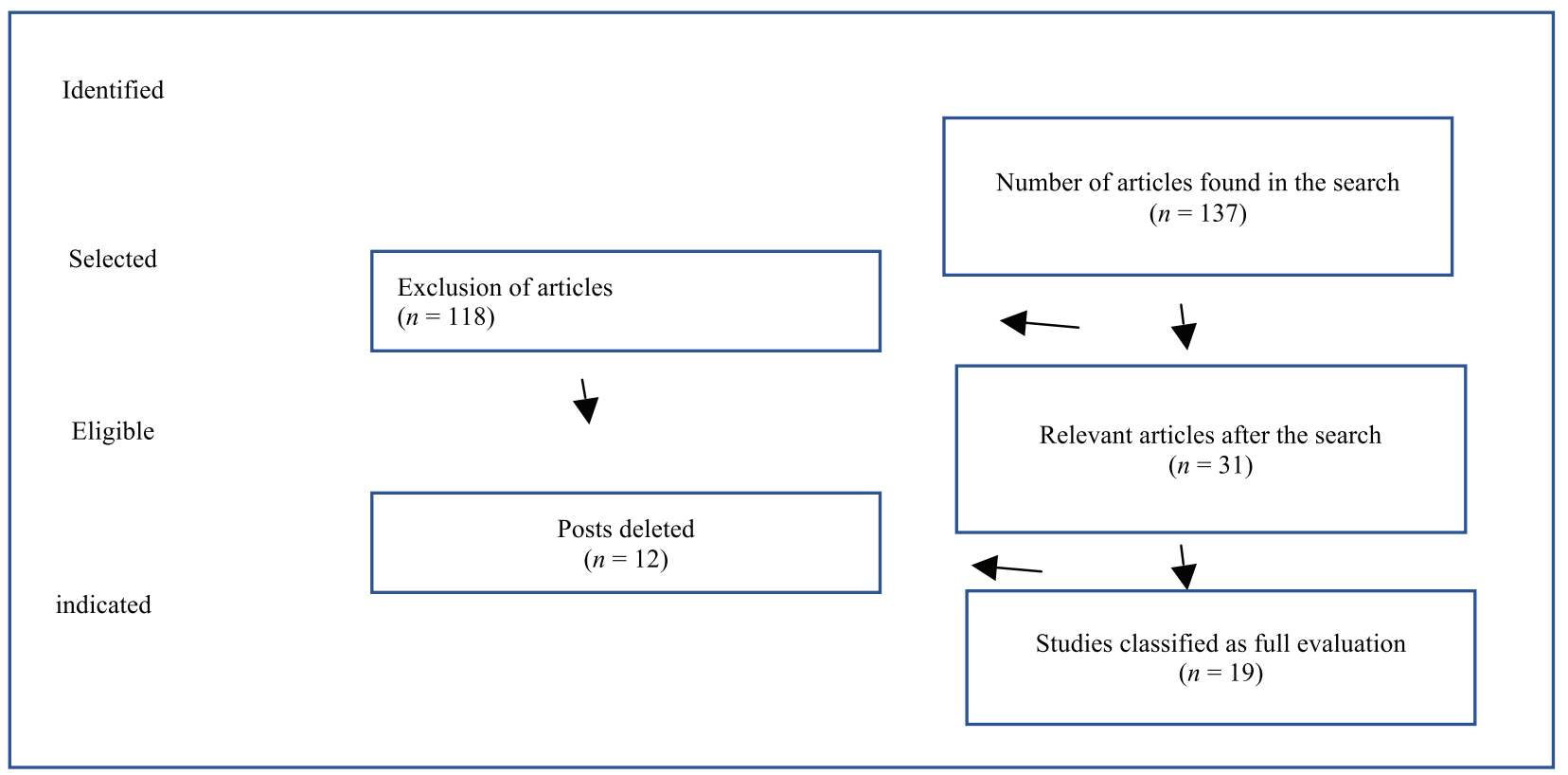

Figure 1. Flowchart for educational interventions in BC. 
Of these articles found, the types of study in the order of predominance were: those of an experimental cut from a quantitative methodology. Of these, six of the selected papers are classified as quasi-experimental; one responds to an experimental design; two claim to be preexperimental studies; two are trials. In addition, a pilot test, a descriptive and a prospective study were carried out. Only three of them were classified as mixed studies, and in two this fact is not mentioned.

Amongst the main topics addressed, we find a predominance of work aimed at promoting, in some way, knowledge about BC, especially linked to self-examination and the prevention of risk factors. Other studies, in order of appearance, respond to awareness/education work. To a lesser extent, there are more specific approaches linked to beliefs, attitudes, behaviours. All studies, however, are aimed at prevention, and it is important to note that in one of them they use technologies as tools to mediate the process of learning.

The countries most represented in these studies are: Colombia, in four; Mexico and Cuba in two studies each. Next, countries that appear in one study such as Peru, Saudi Arabia, Malaysia, Iran, India, Spain Brazil, Ethiopia and England, and two studies that do not contextualise their results. The largest scientific production/publication is associated with the years 2019-2020, with 10 of the publications concentrated in that period.

We observe that 13 of the studies consider interventions in the population of adolescents and young people, whilst 2 of them include also those over 20 years old (up to 60); 5 of them focus only on adults and 1 does not specify the data.

On the other hand, it is observed that, in the studies presented, there is a tendency to use educational strategies where information/discussion/practical exemplification is weighted, rather than active participation in the preventive educational process.

The summary of the particularities of the studies found on educational interventions in BC is presented in Table 1.

Table 1. Revised articles on educational interventions in BC.

\begin{tabular}{|c|c|c|c|c|c|c|c|c|}
\hline No. & Reference & $\begin{array}{l}\text { Data- } \\
\text { base }\end{array}$ & Title & Target & Study type & Sample & $\begin{array}{c}\text { Study } \\
\text { population }\end{array}$ & $\begin{array}{c}\text { Type and number of } \\
\text { sessions }\end{array}$ \\
\hline 1. & $\begin{array}{l}\text { Bernal B, } \\
\text { Figueroa D, } \\
\text { Gutierrez J, } \\
\text { Ramirez R, } \\
\text { Carriño J y } \\
\text { Castellanos } \\
\text { A (2017) }\end{array}$ & $\begin{array}{l}\text { Google } \\
\text { Scholar }\end{array}$ & $\begin{array}{l}\text { Perception and } \\
\text { knowledge of breast } \\
\text { self-examination } \\
\text { before and after an } \\
\text { intervention } \\
\text { Health education for } \\
\text { adolescents in Tunja }\end{array}$ & $\begin{array}{l}\text { Perception and } \\
\text { knowledge of breast self- } \\
\text { examination } \\
\text { before and after an } \\
\text { educational health } \\
\text { intervention in } \\
\text { adolescents of Tunja }\end{array}$ & Mixed & Availability & $\begin{array}{l}\text { Females aged } \\
14-19\end{array}$ & $\begin{array}{l}\text { A Question-based } \\
\text { dynamics of health } \\
\text { education }\end{array}$ \\
\hline 2. & $\begin{array}{l}\text { Masso AM, } \\
\text { Meneses } \\
\text { JF, Correa } \\
\text { JE, Tovar } \\
\text { A, Alba PA } \\
\text { and Charry } \\
\text { CE (2018) }\end{array}$ & PubMed & $\begin{array}{l}\text { Effects of an } \\
\text { educational } \\
\text { intervention on breast } \\
\text { self-examination, } \\
\text { knowledge related } \\
\text { to breast cancer } \\
\text { prevention and healthy } \\
\text { lifestyles in school } \\
\text { children in a low- } \\
\text { income area of Bogotá, } \\
\text { Colombia }\end{array}$ & $\begin{array}{l}\text { To evaluate the effects } \\
\text { of an educational } \\
\text { intervention in the } \\
\text { practice of breast } \\
\text { self-examination, } \\
\text { knowledge and practice } \\
\text { of healthy lifestyles for } \\
\text { the prevention of breast } \\
\text { cancer in female students } \\
\text { of a public school in the } \\
\text { town of Ciudad Bolívar in } \\
\text { Bogotá, Colombia }\end{array}$ & $\begin{array}{l}\text { Does not } \\
\text { mention }\end{array}$ & Availability & $\begin{array}{l}155 \\
\text { adolescent } \\
\text { women } \\
\text { (10-20 years) }\end{array}$ & $\begin{array}{l}\text { Two educational } \\
\text { sessions of } 90 \\
\text { minutes each } \\
\text { The contents of } \\
\text { the intervention } \\
\text { were integrated } \\
\text { into the school } \\
\text { curriculum (videos, } \\
\text { presentations and } \\
\text { discussions) }\end{array}$ \\
\hline
\end{tabular}


Table 1. Revised articles on educational interventions in BC. (Continued)

\begin{tabular}{|c|c|c|c|c|c|c|c|c|}
\hline 3. & $\begin{array}{l}\text { Alameer A, } \\
\text { Mahfouz } \\
\text { MS, Alamir } \\
\text { Y, Ali N and } \\
\text { Darraj A } \\
\text { (2019) }\end{array}$ & PubMed & $\begin{array}{l}\text { Effect of Health } \\
\text { Education on Female } \\
\text { Teachers' Knowledge } \\
\text { and Practices } \\
\text { Regarding Early Breast } \\
\text { Cancer Detection } \\
\text { and Screening in } \\
\text { Jazan Area: a Quasi- } \\
\text { Experimental Study }\end{array}$ & $\begin{array}{l}\text { Evaluation of the } \\
\text { effectiveness of } \\
\text { health education in } \\
\text { the improvement of } \\
\text { knowledge and practices } \\
\text { of primary school } \\
\text { teachers with respect to } \\
\text { detection tools and early } \\
\text { detection of breast cancer }\end{array}$ & $\begin{array}{l}\text { Quasi- } \\
\text { experimental }\end{array}$ & Randomised & $\begin{array}{l}150 \text { primary } \\
\text { school } \\
\text { teachers ( } 75 \\
\text { in the control } \\
\text { group, } \\
75 \text { in the } \\
\text { intervention } \\
\text { group) }\end{array}$ & $\begin{array}{l}\text { Meeting, PowerPoint } \\
\text { presentation and } \\
\text { practical session } \\
\text { ( } 60 \text { minutes each) }\end{array}$ \\
\hline 4. & $\begin{array}{l}\text { Akhtari } \\
\text { M, Juni } \\
\text { MH, Said } \\
\text { SM, Ismail } \\
\text { IZ, Latiff } \\
\text { LA and } \\
\text { Ataollahi S } \\
\text { (2016) }\end{array}$ & PubMed & $\begin{array}{l}\text { Result of a randomized } \\
\text { control trial to } \\
\text { increase breast health } \\
\text { awareness among } \\
\text { young females in } \\
\text { Malaysia }\end{array}$ & $\begin{array}{l}\text { The development, } \\
\text { implementation and } \\
\text { evaluation of the } \\
\text { effectiveness of the } \\
\text { breast health awareness } \\
\text { programme, based on } \\
\text { health beliefs surrounding } \\
\text { knowledge of breast } \\
\text { cancer and breast self- } \\
\text { examination and the } \\
\text { practice of breast self- } \\
\text { examination for female } \\
\text { Malaysian students }\end{array}$ & $\begin{array}{l}\text { Randomised } \\
\text { controlled } \\
\text { trial }\end{array}$ & Randomised & 370 students & $\begin{array}{l}16 \text { workshops lasting } \\
2 \text { hours }\end{array}$ \\
\hline 5. & $\begin{array}{l}\text { Kissal A, } \\
\text { Kartal B } \\
(2019)\end{array}$ & PubMed & $\begin{array}{l}\text { Effects of Health } \\
\text { Belief Model-Based } \\
\text { Education on Health } \\
\text { Beliefs and Breast Self- } \\
\text { Examination in Nursing } \\
\text { Students }\end{array}$ & $\begin{array}{l}\text { Investigation of the } \\
\text { effect of an education } \\
\text { programme based on a } \\
\text { model of health beliefs } \\
\text { (HB) of nursing students } \\
\text { and their practices of } \\
\text { breast self-examination } \\
\text { (BSE) }\end{array}$ & $\begin{array}{l}\text { Semi- } \\
\text { experimental } \\
\text { intervention } \\
\text { with single } \\
\text { group, pre } \\
\text { and post-test } \\
\text { design }\end{array}$ & Not recorded & 48 students & $\begin{array}{l}\text { Use of leaflets as } \\
\text { educational material } \\
\text { Time not referenced }\end{array}$ \\
\hline 6. & $\begin{array}{l}\text { Termeh } \\
\text { Zonouzy, } \\
\text { V., } \\
\text { Niknami, } \\
\text { S., } \\
\text { Ghofranipo } \\
\text { ur, F., y } \\
\text { Montazeri, } \\
\text { A. (2018). }\end{array}$ & PubMed & $\begin{array}{l}\text { An educational } \\
\text { intervention based } \\
\text { on the extended } \\
\text { parallel process model } \\
\text { to improve attitude, } \\
\text { behavioral intention, } \\
\text { and early breast } \\
\text { cancer diagnosis: a } \\
\text { randomized trial }\end{array}$ & $\begin{array}{l}\text { Assessment of the } \\
\text { effectiveness of an } \\
\text { educational intervention } \\
\text { based fear appeals using } \\
\text { the extended parallel } \\
\text { process model (EPPM) } \\
\text { to improve attitudes, } \\
\text { intention and early breast } \\
\text { cancer diagnosis in Iranian } \\
\text { women }\end{array}$ & $\begin{array}{l}\text { Cluster- } \\
\text { randomised } \\
\text { trial with } \\
\text { two parallel } \\
\text { groups }\end{array}$ & Randomised & $\begin{array}{l}438 \text { women, } \\
40 \text { years old } \\
\text { and above }\end{array}$ & $\begin{array}{l}\text { Use of leaflets as } \\
\text { educational material } \\
\text { Time not referenced }\end{array}$ \\
\hline 7. & $\begin{array}{l}\text { Nisha B and } \\
\text { Murali R } \\
(2020)\end{array}$ & PubMed & $\begin{array}{l}\text { Impact of Health } \\
\text { Education Intervention } \\
\text { on Breast Cancer } \\
\text { Awareness among } \\
\text { Rural Women of Tamil } \\
\text { Nadu }\end{array}$ & $\begin{array}{l}\text { Assessment of the } \\
\text { impact of a health } \\
\text { education interventional } \\
\text { programme on breast } \\
\text { health awareness and BSE } \\
\text { among rural women of } \\
\text { Tamil Nadu }\end{array}$ & $\begin{array}{l}\text { Quasi- } \\
\text { experimental }\end{array}$ & Randomised & $\begin{array}{l}266 \text { women } \\
\text { (aged 20-60 } \\
\text { years) }\end{array}$ & $\begin{array}{l}\text { Interactive sessions, } \\
\text { PowerPoint } \\
\text { presentations, } \\
\text { stories } \\
\text { Time not referenced }\end{array}$ \\
\hline
\end{tabular}


Table 1. Revised articles on educational interventions in BC. (Continued)

\begin{tabular}{|c|c|c|c|c|c|c|c|c|}
\hline 8. & $\begin{array}{l}\text { Pons- } \\
\text { Rodriguez } \\
\text { A, Martínez } \\
\text { M, } \\
\text { Perestelo } \\
\text { L, Garcia } \\
\text { M, Sala M, } \\
\text { Rué M and } \\
\text { the InforMa } \\
\text { Group } \\
\text { (2020) } \\
\end{array}$ & PubMed & $\begin{array}{l}\text { Informed choice } \\
\text { in breast cancer } \\
\text { screening: the role of } \\
\text { education }\end{array}$ & $\begin{array}{l}\text { Evaluation of the effect } \\
\text { of receiving information } \\
\text { about the benefits and } \\
\text { harms of breast cancer } \\
\text { screening in informed } \\
\text { choice, according to } \\
\text { educational level }\end{array}$ & Experimental & Randomised & $\begin{array}{l}400 \text { women } \\
\text { (aged 49-50 } \\
\text { years) }\end{array}$ & $\begin{array}{l}\text { Standard leaflet } \\
\text { that recommended } \\
\text { participating in } \\
\text { the screening } \\
\text { programme (control } \\
\text { group) } \\
\text { a decision aid } \\
\text { tool consisting an } \\
\text { informative brochure } \\
\text { (intervention group) } \\
\text { Time not referenced }\end{array}$ \\
\hline 9. & $\begin{array}{l}\text { Pereira } \\
\text { A, Destro } \\
\text { JR, Picinin } \\
\text { M, Garcia } \\
\text { LF and } \\
\text { Rodrigues } \\
\text { TF (2020) }\end{array}$ & PubMed & $\begin{array}{l}\text { Effects of an } \\
\text { WhatsApp-Delivered } \\
\text { Education Intervention } \\
\text { to Enhance Breast } \\
\text { Cancer Knowledge } \\
\text { in Women: Mixed- } \\
\text { Methods Study }\end{array}$ & $\begin{array}{l}\text { Analysis of the potential } \\
\text { of WhatsApp as a } \\
\text { health education } \\
\text { tool used to improve } \\
\text { women's knowledge } \\
\text { on the risk reduction of } \\
\text { breast cancer. Aimed } \\
\text { to understand how } \\
\text { women feel sensitised } \\
\text { within the WhatsApp } \\
\text { group throughout } \\
\text { the intervention and } \\
\text { how they incorporate } \\
\text { information posted to } \\
\text { improve knowledge about } \\
\text { early detection and risk } \\
\text { reduction methods }\end{array}$ & $\begin{array}{l}\text { Mixed- } \\
\text { methods }\end{array}$ & Not recorded & $\begin{array}{l}35 \text { women } \\
\text { (between } 45 \\
\text { and } 69 \text { years } \\
\text { old) }\end{array}$ & $\begin{array}{l}3 \text { weeks after } \\
\text { starting to use } \\
\text { WhatsApp as a } \\
\text { health education } \\
\text { tool }\end{array}$ \\
\hline 10. & $\begin{array}{l}\text { Abera H, } \\
\text { Mengistu D } \\
\text { and Bedaso } \\
\text { A (2017) }\end{array}$ & PubMed & $\begin{array}{l}\text { Effectiveness of } \\
\text { planned teaching } \\
\text { intervention on } \\
\text { knowledge and } \\
\text { practice of breast self- } \\
\text { examination among } \\
\text { first year midwifery } \\
\text { students }\end{array}$ & $\begin{array}{l}\text { The aim of the study is to } \\
\text { assess the effectiveness } \\
\text { of planned teaching } \\
\text { programme on knowledge } \\
\text { and practice of breast } \\
\text { self-examination among } \\
\text { first year midwifery } \\
\text { students in Hawassa } \\
\text { Health Sciences College }\end{array}$ & $\begin{array}{l}\text { Pre- } \\
\text { experimental }\end{array}$ & Randomised & $\begin{array}{l}61 \text { students } \\
\text { aged } 20 \pm 2 \\
\text { years }\end{array}$ & $\begin{array}{l}\text { Theoretical (module) } \\
\text { and practical } \\
\text { sessions based } \\
\text { around knowledge } \\
\text { and practice such } \\
\text { as conferences, } \\
\text { audiovisual } \\
\text { and practical } \\
\text { demonstrations }\end{array}$ \\
\hline 11. & $\begin{array}{l}\text { Soto-Perez } \\
\text { E, Smith } \\
\text { DD, Rojo } \\
\text { MP, Hurria } \\
\text { A, Pavas } \\
\text { AM, Gitler } \\
\text { R, Mohar } \\
\text { A and } \\
\text { Chavarri Y } \\
\text { (2017) }\end{array}$ & PubMed & $\begin{array}{l}\text { Implementation } \\
\text { of a School-Based } \\
\text { Educational Program } \\
\text { to Increase Breast } \\
\text { Cancer Awareness } \\
\text { and Promote } \\
\text { Intergenerational } \\
\text { Transmission of } \\
\text { Knowledge in a Rural } \\
\text { Mexican Community }\end{array}$ & $\begin{array}{l}\text { We tested the feasibility } \\
\text { of implementing a school- } \\
\text { based breast cancer } \\
\text { educational programme } \\
\text { for adolescents in a rural } \\
\text { Mexican community }\end{array}$ & Pilot study & Not recorded & $\begin{array}{l}114 \\
\text { adolescent } \\
\text { students }\end{array}$ & $\begin{array}{l}5 \text { information and } \\
\text { discussion sessions } \\
\text { (40 minutes) }\end{array}$ \\
\hline
\end{tabular}


Table 1. Revised articles on educational interventions in BC. (Continued)

\begin{tabular}{|c|c|c|c|c|c|c|c|c|}
\hline 12. & $\begin{array}{l}\text { Omrani A, } \\
\text { Wakefield } \\
\text { J, Smith J, } \\
\text { Wadey R } \\
\text { and Brown } \\
\text { N (2020) }\end{array}$ & PubMed & $\begin{array}{l}\text { Breast Education } \\
\text { Improves Adolescent } \\
\text { Girls' Breast } \\
\text { Knowledge, Attitudes } \\
\text { to Breasts and } \\
\text { Engagement with } \\
\text { Positive Breast Habits }\end{array}$ & $\begin{array}{l}\text { Evaluation of the short- } \\
\text { and longer-term impact } \\
\text { of a } 50 \text { minute breast } \\
\text { education intervention on } \\
\text { adolescent girls' (11-14 } \\
\text { years) breast knowledge, } \\
\text { attitudes to breasts and } \\
\text { engagement with positive } \\
\text { breast habits }\end{array}$ & $\begin{array}{l}\text { A mixed } \\
\text { methods, } \\
\text { controlled, } \\
\text { longitudinal, } \\
\text { cohort } \\
\text { design, using } \\
\text { two control } \\
\text { schools } \\
\text { (n: } 412 ; \\
\text { receiving no } \\
\text { intervention) } \\
\text { and two } \\
\text { intervention } \\
\text { schools } \\
\text { (n: } 375 ; \\
\text { receiving the } \\
\text { intervention) }\end{array}$ & Availability & $\begin{array}{l}787 \text { students } \\
\text { (11-14 years) }\end{array}$ & $\begin{array}{l}\text { One } 50 \text { minute } \\
\text { session consisting } \\
\text { discussion groups } \\
\text { and a PowerPoint } \\
\text { slideshow } \\
\text { presentation }\end{array}$ \\
\hline 13. & $\begin{array}{l}\text { Hernández } \\
\text { I, González } \\
\text { Y, Heredia } \\
\text { L, Heredia } \\
\text { A, Conde M } \\
\text { and Aguilar } \\
\text { S (2011) }\end{array}$ & SciELO & $\begin{array}{l}\text { Education intervention } \\
\text { on early breast cancer } \\
\text { detection }\end{array}$ & $\begin{array}{l}\text { To increase the level of } \\
\text { knowledge of early breast } \\
\text { cancer detection } \\
2011\end{array}$ & $\begin{array}{l}\text { Does not } \\
\text { mention }\end{array}$ & $\begin{array}{l}\text { Random } \\
\text { probability } \\
\text { sampling }\end{array}$ & 352 women & $\begin{array}{l}\text { Four training } \\
\text { modules } \\
\text { which included } \\
\text { participatory } \\
\text { techniques (group } \\
\text { discussions and } \\
\text { educational games) } \\
\text { which lasted an hour } \\
\text { for each group, once } \\
\text { a week, for } 3 \text { months }\end{array}$ \\
\hline 14. & $\begin{array}{l}\text { Gisela } \\
\text { González } \\
\text { Ruiz, } \\
\text { Orlando } \\
\text { Peralta } \\
\text { González, } \\
\text { Dayana } \\
\text { Judith de la } \\
\text { Rosa (2019) }\end{array}$ & SciELO & $\begin{array}{l}\text { Impact of an } \\
\text { educational } \\
\text { intervention on breast } \\
\text { cancer knowledge in } \\
\text { Colombian women }\end{array}$ & $\begin{array}{l}\text { Evaluation of the } \\
\text { impact of educational } \\
\text { intervention on } \\
\text { knowledge of breast } \\
\text { cancer in a group of } \\
\text { adult women in Santa } \\
\text { Marta.2020 }\end{array}$ & $\begin{array}{l}\text { Quasi- } \\
\text { experimental }\end{array}$ & $\begin{array}{l}\text { Non- } \\
\text { probabilistic } \\
\text { sample }\end{array}$ & $\begin{array}{l}96 \text { women } \\
\text { aged over of } \\
20 \text { years }\end{array}$ & $\begin{array}{l}\text { Educational chats, } \\
\text { teaching discussions } \\
\text { and demonstrations } \\
\text { on the self-breast- } \\
\text { examination } \\
\text { technique }\end{array}$ \\
\hline 15. & $\begin{array}{l}\text { Amaya- } \\
\text { Nieto M, } \\
\text { Prado- } \\
\text { Avendaño } \\
\text { K, and } \\
\text { Velásquez } \\
\text { Carranza D } \\
\text { (2015). }\end{array}$ & $\begin{array}{l}\text { Google } \\
\text { Scholar }\end{array}$ & $\begin{array}{l}\text { Educational } \\
\text { Intervention Efficacy in } \\
\text { the level of knowledge } \\
\text { about Breast Cancer in } \\
\text { Tiwinsa-Puente Piedra } \\
\text { Shanty Town Women }\end{array}$ & $\begin{array}{l}\text { To determine the } \\
\text { effectiveness of an } \\
\text { educational intervention } \\
\text { on the level of knowledge } \\
\text { of breast cancer in } \\
\text { women between } 30 \text { and } \\
65 \text { years of age created } \\
\text { in Tiwinza Shanty Town, } \\
\text { Puente Piedra in } 2012\end{array}$ & $\begin{array}{l}\text { Pre- } \\
\text { experimental }\end{array}$ & $\begin{array}{l}\text { Probability } \\
\text { sampling }\end{array}$ & $\begin{array}{l}61 \text { women } \\
\text { aged } \\
\text { between } 30 \\
\text { and } 65 \text { years } \\
\text { old }\end{array}$ & $\begin{array}{l}\text { Details of the } \\
\text { intervention not } \\
\text { referenced }\end{array}$ \\
\hline
\end{tabular}


Table 1. Revised articles on educational interventions in BC. (Continued)

\begin{tabular}{|c|c|c|c|c|c|c|c|c|}
\hline 16. & $\begin{array}{l}\text { Scott R, } \\
\text { Ramírez AF, } \\
\text { Desten A } \\
\text { and Soto O } \\
\text { (2019) }\end{array}$ & SciELO & $\begin{array}{l}\text { Educational } \\
\text { intervention on breast } \\
\text { cancer in women, } \\
\text { University Polyclinic } \\
\text { 'Emilio Daudinot } \\
\text { Bueno', Guantánamo } \\
\text { 2017-2018 }\end{array}$ & $\begin{array}{l}\text { To design an educational } \\
\text { intervention aimed at } \\
\text { raising the preparation } \\
\text { on the subject in women } \\
\text { from } 18 \text { and } 60 \text { years of } \\
\text { the Family Office } 12 \text { of } \\
\text { the University Polyclinic } \\
\text { 'Emilio Daudinot Bueno' }\end{array}$ & Prospective & Availability & $\begin{array}{l}97 \text { women } \\
18-60 \text { years }\end{array}$ & $\begin{array}{l}\text { It was established } \\
\text { in three phases. The } \\
\text { first phase focused } \\
\text { on the level of } \\
\text { knowledge on the } \\
\text { subject; the second } \\
\text { stage involved the } \\
\text { design and execution } \\
\text { of the educational } \\
\text { intervention. Three } \\
\text { weekly educational } \\
\text { sessions took } \\
\text { place, lasting } 50 \\
\text { minutes. The third } \\
\text { stage entailed } \\
\text { an evaluation } \\
\text { of the results of } \\
\text { the educational } \\
\text { intervention }\end{array}$ \\
\hline 17. & $\begin{array}{l}\text { Gisela } \\
\text { González } \\
\text { Ruiz, } \\
\text { Orlando } \\
\text { Peralta } \\
\text { González, } \\
\text { Dayana } \\
\text { Judith de la } \\
\text { Rosa (2019) }\end{array}$ & SciELO & $\begin{array}{l}\text { Impact of an } \\
\text { educational } \\
\text { intervention on breast } \\
\text { cancer knowledge in } \\
\text { Colombian women }\end{array}$ & $\begin{array}{l}\text { Evaluation of the } \\
\text { impact of educational } \\
\text { intervention on } \\
\text { knowledge of breast } \\
\text { cancer in a group of adult } \\
\text { women in Santa Marta }\end{array}$ & $\begin{array}{l}\text { Quasi- } \\
\text { experimental }\end{array}$ & $\begin{array}{l}\text { Non- } \\
\text { probabilistic } \\
\text { sample }\end{array}$ & $\begin{array}{l}96 \text { women } \\
\text { over the age } \\
\text { of } 20\end{array}$ & $\begin{array}{l}3 \text { sessions } \\
15 \text { workshops }\end{array}$ \\
\hline 18. & $\begin{array}{l}\text { María } \\
\text { Martínez } \\
\text { Haro, Ma } \\
\text { Dolores } \\
\text { Quiñoz } \\
\text { Gallardo, } \\
\text { María Porta } \\
\text { Sanfeliu } \\
\text { (2015) }\end{array}$ & $\begin{array}{l}\text { Google } \\
\text { Scholar }\end{array}$ & $\begin{array}{l}\text { Educational } \\
\text { intervention about } \\
\text { breast cancer } \\
\text { prevention with health } \\
\text { professionals within a } \\
\text { hospital setting }\end{array}$ & $\begin{array}{l}\text { Improve the knowledge } \\
\text { of health professionals } \\
\text { on prevention and health } \\
\text { promotion related to } \\
\text { the prevention and early } \\
\text { diagnosis of breast cancer }\end{array}$ & $\begin{array}{l}\text { Assessment } \\
\text { by } \\
\text { knowledge } \\
\text { comparison } \\
\text { pre and } \\
\text { post an } \\
\text { educational } \\
\text { intervention }\end{array}$ & $\begin{array}{l}\text { Does not } \\
\text { mention }\end{array}$ & $\begin{array}{l}106 \text { women/ } \\
\text { men over the } \\
\text { age of } 20 \\
\text { years (doctor, } \\
\text { nurse, } \\
\text { nursing } \\
\text { assistant, } \\
\text { non-health } \\
\text { professionals) }\end{array}$ & $\begin{array}{l}3 \text { theoretical- } \\
\text { practical workshops } \\
\text { with audiovisual } \\
\text { media (video, } \\
\text { Power Point } \\
\text { presentation), lasting } \\
2 \text { hours every } 15 \\
\text { days }\end{array}$ \\
\hline
\end{tabular}


Table 1. Revised articles on educational interventions in BC. (Continued)

\begin{tabular}{|c|c|c|c|c|c|c|c|c|}
\hline 19. & $\begin{array}{l}\text { Ma. del } \\
\text { Rocío } \\
\text { Figueroa } \\
\text { Varela } \\
\text { Gloria } \\
\text { Alejandra } \\
\text { Vega } \\
\text { Guerrero } \\
\text { Raquel } \\
\text { Rocío } \\
\text { Hernández } \\
\text { Pacheco } \\
\text { (2020) }\end{array}$ & SciELO & $\begin{array}{l}\text { Breast health self-care } \\
\text { teaching strategies } \\
\text { for young university } \\
\text { students }\end{array}$ & $\begin{array}{l}\text { To assess the } \\
\text { effectiveness of three } \\
\text { teaching strategies } \\
\text { for self-care of breast } \\
\text { health, in state university } \\
\text { students in Nayarit } \\
\text { Mexico }\end{array}$ & $\begin{array}{l}\text { Quantitative } \\
\text { and } \\
\text { transversal, } \\
\text { with scope } \\
\text { descriptive }\end{array}$ & $\begin{array}{l}\text { Non- } \\
\text { probabilistic } \\
\text { convenience } \\
\text { sampling }\end{array}$ & $\begin{array}{l}63 \text { students } \\
(12 \text { men and } \\
51 \text { women) }\end{array}$ & $\begin{array}{l}\text { Workshops based } \\
\text { on: } \\
\text { alternative strategy } \\
\text { (4 hours combining } \\
\text { various participative } \\
\text { teaching methods) } \\
\text { peer tutoring } \\
\text { strategy ( } 2 \\
\text { hours, informal } \\
\text { presentation } \\
\text { and participative } \\
\text { educational } \\
\text { workshop activities) } \\
\text { traditional strategy } \\
\text { (2 hours, informal } \\
\text { presentation using } \\
\text { a transmission/ } \\
\text { reception model) }\end{array}$ \\
\hline
\end{tabular}

Source: Ortega-Jiménez MC. 2021

\section{Discussion}

Within the studies found, health education is addressed in a general sense, being considered as a dynamic and continuous process that includes self-care behaviours, compliance with healthcare requirements, recommendations, satisfaction in caring for health and adjustments in the person's quality of life [28].

Prevention activities include educational communication with the public to create awareness of risk factors and to promote $\mathrm{HL}$ which can contribute to reducing BC morbidity, as well as promoting demand for early detection in order to improve opportunities for diagnosis and treatment $[29,30]$. Furthermore, consideration is given to the need to establish BC detection strategies and define methods to improve prevention based on educational intervention [31], as well as preventative methods for modifiable risk factors.

One of the modifiable risk factors most often cited in this bibliographical review is regular breast examination. The tendency cited is towards nonexistent or inadequate self-examination. It is noted that women are unaware of how often self-examination should be done or of its usefulness in early detection of cancer [32,33]. It is important to emphasise the need for breast self-examination within a community and to make that need visible, as a means of promoting women's health and as a primary method of preventing BC. This practice needs to be one of the priorities within primary healthcare [34, 35].

The strategies which have been provided at international and national levels in terms of prevention and promotion of health include: breast examination, mammography and early detection [36].

In this context, it was found that interventions addressing awareness, attitudes and practices relating to breast self-examination in adolescent women provide positive results [34], other studies in young people state that breast self-examination should be carried out from the age of 20 onwards. However, a percentage of the population surveyed is unaware of this and there is considerable ignorance about the age at which breast examination should start [32]. Other studies in young people mention that those who managed to acquire a level of awareness of risk factors and BC did not put this into practice in their daily life [28, 37-39].

With respect to people's knowledge of and attitudes towards BC, they indicate that these vary depending on age and marital status, with a pronounced lack of awareness of preventive measures and risk factors for BC among young and single people [5, 40]. 
Another noteworthy element in relation to breast self-examination is failure to take the menstrual cycle into account, as a factor for consideration in good practice, which indicates a persistent failing in this aspect, showing the need to educate all age groups [41].

It was found that in interventions in the 30-65 years age range, there is insufficient knowledge about BC. However, after the educational intervention, there was generally a very good level and following the intervention no women were found to have a poor level of knowledge $[42,43]$.

Mention was made of the need to implement health promotion and education strategies to tackle non-transmissible diseases and other health conditions. Particular emphasis was placed on working to reduce premature mortality due to BC. In this respect, it is essential to address BC from an epidemiological-preventive and social perspective, instead of merely placing it within a curative care paradigm [44].

Several studies have been carried out in which education and health are structured as connecting axes in preventing the appearance of BC, including basic information on cancer facts and figures, BC epidemiology, risk factors for developing cancer, signs and symptoms, etc., $[28,45]$.

After analysing the data, it can be said that the level of awareness in individuals who participated in the studies contained in the research shown increased significantly [43] as a result of the various educational interventions on BC, particularly in aspects concerning new information and early detection methods. This indicates that the educational interventions are effective, managing to significantly increase the level of awareness in all their variants, leading to future quality of life through timely detection, linked with prevention and control of the disease and with improvements in life styles [33, 37, 46-60].

These results corroborate the need to develop policies that guide the development of information, education and counselling programmes in order to strengthen awareness of risk factors, and the signs and symptoms that require immediate health care, in connection with BC $[36,38]$.

It is therefore necessary to design new teaching methods based on these educational interventions in order to increase the efficiency of the teaching/learning process in health education, and its relationship with BC, since the government has not so far managed to make an impact in early detection of this condition [34, 61, 62].

In this light, educational initiatives have been recommended as effective public measures for the integrated control of BC, particularly among young people [28, 33, 37].

It should be stressed that lack of health education is a predisposing factor that prevents women and men of all ages from obtaining precise information about what they need to do to prevent BC, and to detect it at an early stage. Self-examination of the breasts is considered one of the core aspects of such education, as it enables timely detection of changes such as benign nodules, cysts, etc.

In the context of these searches, there is evidence about educational interventions to prevent BC in the under 20 s, so emphasis is placed on the need to ensure successful intervention from an early age [28, 47].

On the other hand, it can be seen that the male population barely participates in this learning process, demonstrating the urgent need to develop educational interventions that include not only women, but also men, since according to these figures $98 \%$ of cases in males are diagnosed at an advanced stage of the disease, worsening their prognosis compared to women [63]. For example, in the present study, only one research project was found that covered both sexes.

It is therefore necessary for educational programmes to be designed and implemented with an emphasis on a change in attitudes towards health promotion [42].

It is recommended that providers of information on BC make use of educational interventions to reduce mortalities and promote women's health [64]. It will be necessary to expand the intervention to more people and other health areas in order to more precisely demonstrate its reliability. It would also be advisable to make a technical assessment of the viability of interventions that have been designed, and measure their impact on early diagnosis of this type of cancer [28].

Certain characteristics have been identified which increase the effectiveness of educational interventions. These findings points to the development of programmes designed with integrated interventions. These should include aspects linked to quality of life, social and family 
support. The may be periodic or include follow-up over time, mix teaching approaches, make use of those that involve greater participation by attendees. They will need to be assessed using experimental methods, validated and reliable instruments that take into account process indicators, and quality of care results from attendees [28, 65].

\section{Conclusions}

BC education interventions are effective, low-cost strategies, which can encourage their implementation in health policies. Nevertheless, they should be addressed to men and women, at all stages of life, encouraging self-care through prevention and health promotion. They should look at dietary factors, physical activity, Body Mass Index, alcohol consumption, hormonal factors, breast self-examination, thus helping to develop HL. Although incidence is very low in males compared to females, the diagnosis has a higher mortality rate due to late detection. All of this calls for multidisciplinary health interventions, not forgetting that in order to achieve the desired impact, there needs to be long-term follow-up, to verify whether the aims of the intervention are being met.

\section{Conflicts of interest and funding}

Funded by the University of Guanajuato.

\section{Acknowledgments}

The authors would like to thank the University of Guanajuato and the International Iberoamerican University, Mexico, for science training.

\section{References}

1. Fuentes T, Camacho J, and Cadiz F (2019) Diagnóstico y manejo del cáncer de mama Contacto Cientifico 9 13-19 [http://contactocientifico.alemana.cl/ojs/index.php/cc/article/view/640/568] Date accessed: 14/06/19

2. Kolak A, Kamińska M, and Ciszewski T, et al (2015) Breast cancer risk factors Menopausal Rev 3 196-202 Date accessed: 14/06/19 https://doi.org/10.5114/pm.2015.54346

3. Tao Z, Shi A, and Lu C, et al (2015) Breast cancer: epidemiology and etiology Biochem Biophys 72 333-338 Date accessed: 14/06/19 https://doi.org/10.1007/s12013-014-0459-6

4. Legesse E, Dechassa W and Sufa A (2017) Assessment of breast self-examination practice and associated factors among female health professionals in Western Ethiopia: a cross sectional study Int J Med Med Sci 9 148-157 Date accessed: 14/07/19 https://doi. org/10.5897/IJMMS2016.1269

5. Dornelles Prolla C, Santos da Silva O, and Oliveira Netto C, et al (2015) Conocimiento del cáncer de mama y cáncer de mama hereditario en el personal de enfermería de un hospital público Rev Lat Am Enfermagem 23 90-97 Date accessed: 14/07/19 https://doi. org/10.1590/0104-1169.0185.2529

6. Reyes D, Cruz A, and Jaimes E, et al (2016) Prevalence overweight and obesity to the Body Mass Index and percentage of fat in patients with breast cancer Nutr Clín Diet Hosp 36 10-13 Date accessed: 14/07/19 https://doi.org/10.12873/363reyesbarretero

7. Carrión-Peñalve R, Castellanos-Carmenate T, \& Pérez-Salinas L, et al (2017) Incidencia de algunos factores sociales en el incremento del cáncer de mama Medisan 21298 [http://scielo.sld.cu/pdf/san/v21n3/san08203.pdf] Date accessed: 14/06/20 
8. Torres-Aja L and Caballero-Aja N (2016) Cáncer de mama masculino: estudio de 36 años. Comportamiento en la provincia de Cienfuegos Scielo 6 274-280 Date accessed: 14/08/19

9. Miao H, Verkooijen $\mathrm{H}$, and Chia $\mathrm{K}$, et al (2011) Incidence and outcome of male breast cancer: an international population-based study J Clin Oncol 29 4381-4386 https://doi.org/10.1200/JCO.2011.36.8902 PMID: 21969512

10. Dórame-López N, Tejada-Tayabas L, and Galarza-Tejada, D et al (2017) Detección precoz del cáncer en la mujer, enorme desafío de salud en México. Algunas reflexiones Rev Salud Públ Nutr 16 14-22 Date accessed: 14/08/19 https://doi.org/10.29105/respyn16.3-3

11. López Z, González Ortega J, and Garcia R, et al (2018) Cáncer de mama en mujeres jóvenes. Presentación de dos casos Rev Méd Electrón 40 1186-1196 [http://scielo.sld.cu/pdf/rme/v40n4/rme250418.pdf]

12. Villarreal-Garza G (2015) Cáncer de mama en mujeres jóvenes. Experiencia en el Instituto Nacional de Cancerología Rev Mexicana Mastología 17 12-17 [https://www.medigraphic.com/pdfs/revmexmastol/ma-2015/ma151c.pdf] Date accessed: 14/09/19

13. Padrón O, Otero I, and De la Cruz D, et al (2016) Intervención educativa sobre enfermedades benignas mamarias y autoexamen de mama Rev Cubana Med Gen Integr 32 161-169 [http://scielo.sld.cu/pdf/mgi/v32n2/a03.pdf] Date accessed: 14/09/19

14. Santibáñez-Ramírez M, Símbala-Delgado A, and Valenzuela-Núñez N, et al (2019) Conocimiento del cáncer de mama en estudiantes de enfermería Ciencia Y Enfermería 25 1-7 Date accessed: 14/10/19 https://doi.org/10.4067/s0717-95532019000100205

15. Sánchez G, Laza C, and Estupiñán C, et al (2014) Barreras de acceso a los servicios de salud: narrativas de mujeres con cáncer de mama en Colombia Rev Fac Nac Salud Pública 32 305-313 [http://www.scielo.org.co/pdf/rfnsp/v32n3/v32n3a05.pdf] Date accessed: $14 / 10 / 19$

16. Ruco A, Dossa F, and Tinmouth J, et al (2020) Social media and mobile health technology for cancer screening: a systematic review and meta-analysis protocol BMJ Open 10 1-5 Date accessed: 14/11/19 https://doi.org/10.1136/bmjopen-2019-035411

17. Zhang Y, Pan X, and Chen J, et al (2020) Combined lifestyle factors, incident cancer, and cancer mortality: a systematic review and meta-analysis of prospective cohort studies Br J Cancer 68 394-424 Date accessed: 14/12/19 https://doi.org/10.1038/s41416-020$\underline{0741-x}$

18. Cárdenas-Sánchez J, Bargalló-Rocha E, and Erazo Valle A, et al (2013) Consenso Mexicano sobre diagnóstico y tratamiento del cáncer mamario Gac Mexicana Oncología 12 4-55 [http://www.gamo-smeo.com/temp/CANCER\%20DE\%20MAMA.pdf] Date accessed: $14 / 12 / 19$

19. Mohar A, Reynoso N, and Villarreal-Garza C, et al (2015) Cáncer de mama en el Instituto Nacional de Cancerología. Experiencia del Seguro Popular 2007-2013 Rev Mexicana de Mastología 5 6-11 [https://www.medigraphic.com/cgi-bin/new/resumen.cgi?IDARTICULO=60034] Date accessed: 14/06/20

20. Padilla-Raygoza N, Monroy-Torres R, and Sandoval-Salazar C, et al (2020) Cancer prevention programmes in Mexico: are we doing enough? Ecancermedicalscience 14997 Date accessed: 14/01/20 https://doi.org/10.3332/ecancer.2020.997

21. Coughlin S, Yoo W, and Whitehead MS et al (2015) Avanzando en la supervivencia del cáncer de mama entre las mujeres afroamericanas Breast Cancer Res Treat 153 253-261 [https://www.breastcancer.org/es/noticias-investigacion/20130114] Date accessed: 14/01/20 https://doi.org/10.1007/s10549-015-3548-3 PMID: 26303657 PMCID: 4560975

22. Sánchez-Urdaneta Y, Urdaneta-Machado J, and Villalobos-Inciarte N, et al (2016) Conocimiento sobre cáncer de mamas y práctica del autoexamen de mamas en mujeres de edad mediana Rev Venez Oncología 28 37-51 [https://www.redalyc.org/ jatsRepo/3756/375643222006/html/index.html] Date accessed: 14/02/20

23. Sardiñas R (2019) Breast self exam: an important tool of breast cancer prevention in primary health care Rev Habanera Cienc Méd 8 1-10 [http://scielo.sld.cu/scielo.php?script=sci_arttext\&pid=s1729-519x2009000300005] Date accessed: 14/02/20 
24. León-Díaz R, Chaparro-García M, and López-Mora G, et al (2019) Efecto de la sinergia de losfactores de riesgo para cáncer de mama en muje-res de la ciudad de Veracruz Rev de Senología Patol Mamaria 32 3-11 Date accessed: 14/02/20 https://doi.org/10.1016/j. senol.2019.01.003

25. Pruitt C, Odedina S, and Anetor I, et al (2020) Evaluación del conocimiento sobre el cáncer de mama en trabajadores de la salud en Ibadan, suroeste de Nigeria JCO Glob Oncol 6 387-394 [https://ascopubs.org/doi/full/10.1200/JGO.19.00260] Date accessed: 14/02/20 https://doi.org/10.1200/JGO.19.00260 PMID: 32125900 PMCID: 7126761

26. Bernal B, Figueroa D, and Gutierrez J, et al (2017) Percepción y conocimiento del autoexamen de mama antes y después de una intervención educativa de salud en adolescentes Rev Salud Hist Sanid Online 12 4-15 [http://agenf.org/ojs/index.php/shs/article/view/179/177] Date accessed: $14 / 06 / 20$

27. Noman S, Shahar H, and Abdul Rahman H et al (2020) Effectiveness of an educational intervention of breast cancer screening practices uptake, knowledge, and beliefs among Yemeni female school teachers in Klang Valley, Malaysia: a stud protocol for a cluster-randomized controlled trial Int J Environ Res Public Health 171167 Date accessed: 14/02/20 https://doi.org/10.3390/ijerph17041167

28. Paz soto E, Masalan E, and Barrios S (2018) La educación para la salud, elemento central del cuidad Rvdo Med Clin 29 288-300 [https:// reader.elsevier.com/reader/sd/pii/S0716864018300543?token=6E19A1AF4DBD594752F812575E2AEEA87519487CC9B104FFE4 65D8842BC9BFACA99D21571B11D421B94B0C815A2EDF2D] Date accessed: 14/02/20

29. Carrión-Peñalve R, Castellanos-Carmenate T, and Pérez Salinas L et al (2017) Incidencia de algunos factores sociales en el incremento del cáncer de mama Medisan 21298 [http://scielo.sld.cu/pdf/san/v21n3/san08203.pdf] Date accessed: 14/03/20

30. Puigpinós-Riera R and Serral G (2017) A favor del lazo rosa y la prevención del cáncer de mama: diferentes puntos de vista Gac Sanit 31 253-254 Date accessed: 14/06/20 https://doi.org/10.1016/j.gaceta.2016.10.002

31. Camargo-Ayala E and Pico Melo J (2019) Detección temprana del cáncer de mama: utilidad del autoexamen y la educación Rev Salud Areandina 5 31-43 [https://revia.areandina.edu.co/index.php/Nn/article/view/1352/1233] Date accessed: 14/03/20

32. Castillo I, Bohórquez C, and Palomino J, et al (2016) Conocimientos, actitudes y prácticas sobre el autoexamen de mama en mujeres del área rural de Cartagena Rev U.D.C.A Actual Divulg Cient 19 5-14 Date accessed: 14/03/20 https://doi.org/10.31910/rudca.v19. n1.2016.105

33. Masso AM, Meneses JF, and Correa JE, et al (2018) Effects of an educational intervention on breast self-examination, breast cancer prevention-related knowledge, and healthy lifestyles in scholars from a low-income area in Bogota, Colombia J Canc Educ $33673-679$ Date accessed: 14/03/20 https://doi.org/10.1007/s13187-016-1133-z

34. Figueroa D, Gutierrez J, and Ramirez R, et al (2017) Percepción y conocimiento del autoexamen de mama antes y después de una intervención educativa de salud en adolescentes de Tunja Rev Salud Hist Sanid Online 12 1-13 Date accessed: 14/04/20 https://doi. org/10.1909/shs.v12i2.17

35. Martínez M and Quiñoz M (2015) Intervención educativa sobre prevención del cáncer de mama con profesionales sanitarios del ámbito hospitalario Metas Enferm 18 166-170 [https://www.enfermeria21.com/revistas/metas/articulo/80722/intervencion-educativa-sobreprevencion-del-cancer-de-mama-con-profesionales-sanitarios-del-ambito-hospitalario/] Date accessed: 14/04/20

36. González G, Peralta O, and De la Rosa D (2019) Impact of an educational intervention on the knowledge of breast cancer in Colombian women Rev Cubana Salud Públ 45 1-15 [https://www.medigraphic.com/pdfs/revcubsalpub/csp-2019/csp193b.pdf] Date accessed: $14 / 06 / 20$

37. Cárdenas-Sánchez J, Bargalló-Rocha E, and Erazo-Valle A, et al (2013) Consenso Mexicano sobre diagnóstico y tratamiento del cáncer mamario Gac Mex Oncología 12 4-55 [http://www.gamo-smeo.com/temp/CANCER\%20DE\%20MAMA.pdf] Date accessed: 14/04/20 
38. Vilca-Tapullima C, Quispe-Manrique N, and Vega Fernandez A, et al (2017) Nivel de conocimiento sobre factores de riesgo y prevencion del cancer de mama en los estudiantes del segundo ciclo de la facultad de medicina humana de la universidad ricardo palma en el año 2017 Rev Fac Med Humana 17 45-54 Date accessed: 14/04/20 https://doi.org/10.25176/rfmh.v17.n2.831

39. Alameer A, Mahfouz MS, and Alamir Y, et al (2019) Effect of health education on female teachers' knowledge and practices regarding early breast cancer detection and screening in the Jazan Area: a quasi-experimental study J Cancer Educ 34 865-870 [https://link. springer.com/article/10.1007\%2Fs13187-018-1386-9] Date accessed: 14/04/20 https://doi.org/10.1007/s13187-018-1386-9

40. Getachew S, Tesfaw A, and Kaba M, et al (2020) Perceived barriers to early diagnosis of breast cancer in south and Southwestern Ethiopia: a qualitative study BMC Womens Health 20 2-8 Date accessed: 14/05/20 https://doi.org/10.1186/s12905-020-00909-7

41. Gálvez-Espinosa M, Rodríguez-Arévalo $L$ and Rodríguez-Sánchez C (2015) Conocimiento sobre autoexamen de mama en mujeres de 30 años y más Rev Cubana Med Gen Integral 31 134-142 [http://scielo.sld.cu/pdf/mgi/v31n2/mgi03215.pdf] Date accessed: 14/05/20

42. Nieto A, Mercedes S, and Prado-Avedaños K, et al (2015) Eficacia de una intervención educativa en el nivel de conocimiento sobre prevención de cáncer de mama en mujeres del Asentamiento Humano Tiwinza û Puente Piedra/Educational intervention efficacy in the level of knowledge about breast cancer in Tiwinsa-Puente Piedra Shanty Town Woman 2012 Rev Enferm Herediana $897-103$ [https:// pesquisa.bvsalud.org/portal/resource/pt/lil-786434?lang=e] Date accessed: 14/06/20

43. Pereira A, Destro J, and Picinin-Bernuci M, et al (2020) Effects of a WhatsApp-delivered education intervention to enhance breast cancer knowledge in women: mixed-methods study JMIR Mhealth Uhealth 8 e17430 Date accessed: 14/06/20 https://doi.org/10.2196/17430 PMID: 32706726 PMCID: 7404019

44. Scott R, Ramírez AF, and Desten A, et al (2019) Intervención educativa sobre cáncer de mama en mujeres, Policlínico Universitario "Emilio Daudinot Bueno", Guantánamo 2017-2018 Rev Inf Cient 98 597-607 [http://scielo.sld.cu/scielo.php?script=sci_arttext\&pid=S102899332019000500597\&lng=es\&tlng=en] Date accessed: $14 / 06 / 20$

45. Masoudiyekta L, Rezaei-Bayatiyani H, and Dashtbozorgi B, et al (2018) Effect of education based on health belief model on the behavior of breast cancer screening in women Asia Pac J Oncol Nurs 5 114-120 Date accessed: 14/06/20 https://doi.org/10.4103/apjon. apjon_36_17 PMID: 29379843 PMCID: $\underline{5763428}$

46. Noman S, Shahar H, and Abdul Rahman $\mathrm{H}$ et al (2020) Effectiveness of an educational intervention of breast cancer screening practices uptake, knowledge, and beliefs among yemeni female school teachers in Klang Valley, Malaysia: a study protocol for a cluster-randomized controlled trial Int J Environ Res Public Health 171167 Date accessed: 14/06/20 https://doi.org/10.3390/ijerph17041167 PMCID: 7068409

47. Akhtari M, Juni MH, and Said SM, et al (2016) Result of randomized control trial to increase breast health awareness among young females in Malaysia BMC Public Health 16738 [https://bmcpublichealth.biomedcentral.com/articles/10.1186/s12889-016-3414-1] Date accessed: 14/06/20 https://doi.org/10.1186/s12889-016-3414-1

48. Kissal A and Kartal B (2019) Effects of health belief model-based education on health beliefs and breast self-examination in nursing students Asia Pac J Oncol Nurs 6 403-410 [https://www.apjon.org/text.asp?2019/6/4/403/264051] Date accessed: 14/06/20 https:// doi.org/10.4103/apjon.apjon_17_19 PMID: 31572761 PMCID: 6696807

49. Termeh V, Niknami S, and Ghofranipour F, et al (2018) An educational intervention based on the extended parallel process model to improve attitude, behavioral intention, and early breast cancer diagnosis: a randomized trial Int J Womens Health 11 1-10 [https:// www.dovepress.com/an-educational-intervention-based-on-the-extended-parallel-process-mod-peer-reviewed-article-IJWH\#] Date accessed: 14/06/20 https://doi.org/10.2147/IJWH.S182146

50. Nisha B and Murali R (2020) Impact of health education intervention on breast cancer awareness among rural women of Tamil Nadu Indian J Community Med 45 149-153 Date accessed: 14/06/20 https://doi.org/10.4103/ijcm.IJCM_173_19 PMID: 32905196 PMCID: 7467190 
51. Pons -Rodriguez A, Martínez M, and Perestelo L, et al (2020) Elección informada en el cribado del cáncer de mama: el papel del nivel educativo Gac Sanit 35(3) [https://www.sciencedirect.com/science/article/pii/S0213911120300418?via\%3Dihub] Date accessed: $14 / 06 / 20$

52. Pereira A, Destro JR, and Picinin M, et al (2020) Effects of a WhatsApp-delivered education intervention to enhance breast cancer knowledge in women: mixed-methods study JMIR Mhealth Uhealth 8 e17430 [https://mhealth.jmir.org/2020/7/e17430/] Date accessed: 14/06/20 https://doi.org/10.2196/17430 PMID: 32706726 PMCID: 7404019

53. Abera H, Mengistu D, and Bedaso A (2017) Effectiveness of planned teaching intervention on knowledge and practice of breast selfexamination among first year midwifery students PLoS One 12 e0184636 [https://journals.plos.org/plosone/article?id=10.1371/journal.pone.0184636] Date accessed: 14/06/20 https://doi.org/10.1371/journal.pone.0184636 PMID: 28949972 PMCID: 5614528

54. Soto-Perez E, Smith DD, and Rojo MP, et al (2017) Implementation of a school-based educational program to increase breast cancer awareness and promote intergenerational transmission of knowledge in a rural mexican community Oncologist 22 1249-1256 Date accessed: 14/06/20 https://doi.org/10.1634/theoncologist.2017-0063

55. Omrani A, Wakefield J, and Smith J, et al (2020) Breast education improves adolescent girls' breast knowledge, attitudes to breasts and engagement with positive breast habits Front Public Health 8591927 [https://www.frontiersin.org/articles/10.3389/ fpubh.2020.591927/full] Date accessed: 14/06/20 https://doi.org/10.3389/fpubh.2020.591927 PMID: 33194996 PMCID: 7661432

56. Hernández I, Gonzalez Y, and Heredia L, et al (2011) Educational intervention on the early detection of breast cancer Rev Arch Méd Camagüey 15 487-503 [http://scielo.sld.cu/scielo.php?script=sci_arttext\&pid=S1025-02552011000300007] Date accessed: 14/06/20

57. González G, Peralta O, and De la Rosa D (2019) Impact of an educational intervention on the knowledge of breast cancer in Colombian women Rev Cubana de Salud Pública 45 1-15. [https://www.medigraphic.com/pdfs/revcubsalpub/csp-2019/csp193b.pdf] Date accessed: $14 / 06 / 20$

58. Amaya-Nieto M, Prado-Avendaño K, and Velásquez Carranza D (2012) Eficacia de una intervención educativa en el nivel de conocimiento sobre prevención de cáncer de mama en mujeres del Asentamiento Humano Tiwinza -Puente Piedra Rev Enferm Herediana 8 97-103 [https://revistas.upch.edu.pe/index.php/RENH/article/view/2688] Date accessed: 14/06/20

59. Martínez M, Quiñoz M and Porta M (2015) Intervención educativa sobre prevención del cáncer de mama con profesionales sanitarios del ámbito hospitalario Metas Enferm 18 166-170. [https://www.enfermeria21.com/revistas/metas/articulo/80722/intervencion-educativa-sobre-prevencion-del-cancer-de-mama-con-profesionales-sanitarios-del-ambito-hospitalario/] Date accessed: 14/06/20

60. Figueroa M, Vega G, and Hernandez R (2020) Estrategias de enseñanza para el autocuidado de la salud mamaria en jóvenes universitarios Rev Educateconciencia 28 136-135 [http://tecnocientifica.com.mx/educateconciencia/index.php/revistaeducate/article/ view/66/529] Date accessed: 14/06/20

61. Mereu A, Concu F, and Dessì C, et al (2019) Knowledge about cancer screening programmes in Sardinia J Prev Med Hyg 60 E337-E342 Date accessed: 14/06/20 https://doi.org/10.15167/2421-4248/jpmh2019.60.4.1094

62. Rohaizat M, Faisal-Ghazi $\mathrm{H}$, and Mohamed A, et al (2017) Knowledge and practice of breast self-examination among female non-medical students in University Kebangasaan Malaysia (UKM) in Bangi Malays J Public Health Med 17 51-58 [https://www.mjphm.org.my/ mjphm/journals/2017\%20-\%20Volume\%2017\%20(1)/KNOWLEDGE\%20AND\%2OPRACTICE\%200F\%20BREAST\%20SELF-EXAMINATION\%20AMONG\%20FEMALE\%20NON-MEDICAL\%20STUDENTS\%2OIN\%20UNIVERSITI\%20KEBANGASAAN\%20MALAYSIA\%20(UKM)\%2OIN\%20BANGI.pdf] Date accessed: 14/06/20

63. Torres-Aja L and Aja NC (2016) Cáncer de mama masculino: estudio de 36 años. Comportamiento en la provincia de Cienfuegos Scielo 6 274-280 [http://scielo.sld.cu/pdf/rf/v6n4/rf04406.pdf] 
64. Khiyali Z, Aliyan F, and Kashfi S, et al (2017) Educational intervention on breast self-examination behavior in women referred to health centers: application of health belief model Asian Pac J Cancer Prev 18 2833-2838 Date accessed: 14/06/20 https://doi.org/10.22034/ APJCP.2017.18.10.2833 PMID: 29072430 PMCID: 5747411

65. González OP, Rodríguez IO, and de la Cruz Pérez D et al (2016) Intervención educativa sobre enfermedades benignas mamarias y autoexamen de mama Rev Cubana de Med Gen Integral 32 161-169 [http://scielo.sld.cu/pdf/mgi/v32n2/a03.pdf] Date accessed: 14/06/20 